\title{
Land Tenure and Communities' Vulnerability to Climate Shocks: Insights from the Niger Basin of Benin
}

\section{Boris Odilon Kounagbè Lokonon}

\subsection{Introduction}

In sub-Saharan African (SSA) countries, the agricultural sector is expected to face serious difficulties due to climate change and variability (Fofana 2011). In these countries, agriculture is predominantly rain-fed, and consequently this sector is highly sensitive to climate change and variability. However, agriculture is the mainstay of the economy in most African countries, accounting for around $60 \%$ of Africa's employment and about one-quarter of the gross domestic product (GDP) (AfDB et al. 2015). ${ }^{1}$ Farmers in these countries are mostly engaged in subsistence agriculture. Thus, the impacts of climate shocks and stresses are expected to translate into vulnerability, food and livelihood insecurity, and losses in human capital and in welfare (Davies et al. 2009).

It should be noted that climate-related shocks and stresses are not necessarily expected to lead to negative impacts on agriculture, because they are embedded in the practice of agriculture, and some farmers may develop

B. O. K. Lokonon $(\bowtie)$

Université de Parakou, Parakou, Benin

(C) The Author(s) 2018 
coping and risk management strategies (Davies et al. 2008). Moreover, the frequency of occurrence of climate shocks are expected to increase with climate change (IPCC 2013), and actions in terms of reducing the vulnerability and boosting the resilience of the population are needed. In addition, agriculture is recognized to play an important role in the structural transformation of Africa and in poverty reduction (AfDB et al. 2015).

Vulnerability has negative connotation. Thus, owing to that, resilience which originated in ecology (Holling 1973) is becoming influential in development economics. Resilience is not a pro-poor concept, and therefore it should be used with caution when trying to implement development actions (Béné et al. 2012). In addition, social protection is considered as an important factor in reducing poverty and vulnerability and in boosting resilience (Stern 2008; Davies et al. 2008, 2009; Solórzano 2016). Land tenure security is considered as part of social protection (Mahadevia 2011). Land tenure is relative to the conditions under which farmers hold and occupy the land (Schickele 1952). Therefore, agricultural productivity can be influenced by land tenure through the security (or investment) effect (Gavian and Fafchamps 1996; Yegbemey et al. 2013). For instance, Gavian and Fafchamps (1996) found that land tenure status is determinant in manure application between borrowed and owned fields in Niger; farmers have diverted manure toward the latter. Therefore, secure land tenure is increasingly considered as having an appropriate role in reducing the vulnerability of poor people to climate shocks (Jayne et al. 2003; Callo-Concha et al. 2013; Chagutah 2013). However, some factors such as lack of financial capital and access to technology can impede the potential of land tenure security in lessening vulnerability.

This chapter aims to assess the vulnerability of communities to climate shocks in the Niger basin of Benin and to analyze the extent to which land tenure influences vulnerability using the integrated approach and an econometric regression by taking advantage of two-period pseudo panel data. To date, there is limited understanding of the potential role of land tenure in reducing vulnerability of rural communities to climate shocks.

The remainder of the chapter is organized as follow. Section 8.2 presents the background and the conceptual framework. The specification of the vulnerability and resilience approach is presented in Sect. 8.3. Variables used and data sources are presented in Sect. 8.4. Section 8.5 presents the empirical results and discussion and Sect. 8.6 concludes. 


\subsection{Background and Conceptual Framework}

Assessing the vulnerability of communities to climate shocks is important in identifying and characterizing actions toward strengthening resilience (Kelly and Adger 2000; Islam et al. 2014). Yet, existing literature suggests that individuals and communities that depend on highly climate-sensitive sector such as agriculture are vulnerable and less resilient to climate shocks. The existing literature is related to fishery systems (e.g., Islam et al. 2014), agricultural livelihoods (e.g., Brooks et al. 2005; Vincent 2007; Shewmake 2008; Deressa et al. 2008, 2009; Tesso et al. 2012; Etwire et al. 2013; Simane et al. 2016), and many sectors of the economy (e.g., Dixon et al. 2003; Dunford et al. 2015). However, to date none of them investigated quantitatively the extent to which land tenure affects vulnerability to climate shocks.

Vulnerability of communities to climate shocks is the propensity or predisposition they are to be adversely affected (adapted from IPCC 2014, p. 1775). The three components of vulnerability are exposure, sensitivity, and adaptive capacity of the communities. Exposure has an external dimension, while sensitivity, and adaptive capacity have an internal dimension (Füssel 2007). Exposure is the presence of communities in places and settings that could be adversely affected (adapted from IPCC 2014, p. 1765). Sensitivity refers to the degree to which communities are affected, either adversely or beneficially, by climate shocks (adapted from IPCC 2014, p. 1772). As for adaptive capacity, it is the ability of communities to adjust to climate shocks, to take advantage of opportunities, or to respond to consequences (adapted from IPCC 2014, p. 1758). Adaptive capacity encompasses five types of capital: physical, financial, human, natural, and social capital (Scoones 1998).

As mentioned above, resilience is becoming influential in development economics. Resilience is the capacity of communities to cope with climate shocks, responding or reorganizing in ways that maintain its essential function, identity, and structure, while also maintaining the capacity for adaptation, learning, and transformation (adapted from IPCC 2014, p. 1772). Vulnerability and resilience are related concepts (Turner 2010). Resilience influences adaptive capacity (Klein et al. 2003; Adger 2006). Both vulnerability and resilience recognize adaptive capacity, so they 
overlap through adaptive capacity (Berman et al. 2012). Some scholars view resilience as an integral part of adaptive capacity, while others consider adaptive capacity as a main component of vulnerability (Cutter et al. 2008). Moreover, there are scholars that see resilience and adaptive capacity as nested concepts within an overall vulnerability structure (Cutter et al. 2008). Cutter et al. (2008) viewed resilience and vulnerability as separate but often linked concepts. As for Turner (2010), vulnerability and resilience constitute different but complementary framings. Some researchers employ the term "resilience" to the coping capacity component of its framework, whereas others view vulnerability as an antonym of resilience (Turner 2010). Resilience can be considered as adaptive capacity in the case that it is used with an emphasis on society while also integrating environmental characteristics (Malone 2009). In this chapter, resilience is investigated through adaptive capacity, although resilience is not assumed as a synonym of adaptive capacity.

Scholars recognize the potential of social protection in reducing poverty and moving people into productive livelihoods (Davies et al. 2008). Social protection refers to all initiatives (public and private) which have the potential to reduce the economic and social vulnerability of poor, vulnerable, and marginalized groups, and social protection interventions can be classified as protective, preventive, promotive, and transformative measures (Devereux and Sabates-Wheeler 2004). Consequently, social protection can reduce poverty and move people into productive livelihoods, and is of paramount importance in helping the poorest to reduce their exposure to current and future climate shocks (Davies et al. 2008). Land tenure security is integral part of social protection (Mahadevia 2011).

In SSA, the livelihood of rural communities depends on land as key natural capital (Scoones 1998). Therefore, land tenure appears to be central to vulnerability and resilience research, although it is often overlooked (Berman et al. 2012; Chagutah 2013). Land tenure varies across households, communities, and individuals' characteristics such as gender and social groups. Higher levels of tenure security are considered to be associated with higher living conditions, human development achievements, economic status, and access to entitlements (Mahadevia 2011). Through land tenure security people have protection against their involuntary removal from their land without process of law (Mahadevia 2011). Secure land tenure militates for diversified livelihoods and favor investment in appropriate technologies and 
uptake of sound environment management practices (Economic Commission for Africa 2003; Chagutah 2013). However, land tenure security can lead to environmental degradation in rural areas where farmers operate under customary tenure (Chagutah 2013), and therefore exacerbate vulnerability to climate shocks.

Traditional common property systems constitute the basis of land tenure in rural Northern Benin (Callo-Concha et al. 2013). In Benin, ownership of property is acquired and transmitted by succession, donation, purchase, will, and exchange. Property can also be acquired by accession, incorporation, prescription, and other effects of obligations. In this chapter, the focus is on the institutional arrangements on land: the ways and arrangements through which farmers have access to land (Yegbemey et al. 2013). ${ }^{2}$

\subsection{Specification of the Vulnerability and Resilience Approach}

Following Lokonon (2017) conceptual framework and based on Sect. 8.2, vulnerability and resilience to climate shocks is assessed through an integrated approach using the indicator method. Vulnerability index is calculated as the net effect of adaptive capacity, sensitivity, and exposure.

$$
\text { Vulnerability = adaptivecapacity }-(\text { exposure }+ \text { sensitivity }) .
$$

Weights are assigned to each indicator using the different weighting approach. Therefore, principal component analysis (PCA) (Pearson 1901) is used to attribute weight to the different indicators of the three dimensions of vulnerability to climate shocks. Factor scores from PCA are employed as weights to construct vulnerability indices for each village based on Eq. (8.1). Moreover, each indicator is normalized using the $z$-score standardization, and all the extracted factors from PCA are used due to the multidimensionality nature of vulnerability (Vincent and Cull 2014). Therefore, each factor is weighted by the explained variance.

The extent to which land tenure affects vulnerability is investigated through an econometric analysis. The vulnerability equation is specified as follows: 


$$
v_{i t}=\beta_{0}+Y_{i t} \beta_{1}+X_{i t} \beta_{2}+\vartheta_{i}+\gamma_{i t}
$$

where $X_{i}$ is the set of variables belonging to the three dimensions of vulnerability apart from land tenure variables, $Y_{i}$ is a variable reflecting land tenure security (the percentage of crop land which is owned by the farmers themselves), $\beta_{0}, \beta_{1}$, and $\beta_{2}$ are the vectors of the coefficients to be estimated, and $\vartheta_{i}+\gamma_{i t}$ is the error term. All the variables used cannot be included in the regression for the sake of degree of freedom. Therefore, relevant regressors are chosen among the variables used to build vulnerability index through stepwise analyses. Panel specification tests are run to select the appropriate model (Baltagi 2008). Land tenure security is expected to negatively and significantly influence vulnerability to climate shocks. It should be noted that the variable capturing land tenure may be endogenous. Therefore, this chapter accounts for this likely endogeneity and use as instruments the departments in which the communities belong. Indeed, land tenure may vary with respect to the geographic settings.

Moreover, every model has to be tested for sensitivity and uncertainty. A Monte Carlo analysis (Metropolis and Ulam 1949) is performed to assess the uncertainty within the vulnerability index calculation model. Monte Carlo method calculates new results by relying on repetitive random sampling (Metropolis and Ulam 1949). The sensitivity of the vulnerability indicator to any variability in the input dataset is investigated through the change and omission of certain indicators.

\subsection{Description of the Variables and Data}

Variables that are used for the analysis capture the three aspects of the Intergovernmental Panel on Climate Change (IPCC) definition of vulnerability (exposure, sensitivity, and adaptive capacity). Adaptive capacity reflects the five capitals: physical, financial, human, natural, and social capital (Scoones 1998). According to Deressa et al. (2008), exactly how climate shocks affect income or any proxy of livelihood could be the best measure of sensitivity. However, it was not possible to find relevant data, so this research relies on the assumption that areas that experience climate shocks are subject to sensitivity due to loss in yield and thus in income. 
Exposure variables capture changes in temperature and in rainfall from long-term mean (1952-2012), under the assumption that areas with higher changes in temperature and precipitation are most exposed to climate shocks. Table 8.1 presents the indicators used to assess vulnerability and resilience to climate shocks.

Two datasets are used for the analysis: 1998 small farmer survey data from the International Food Policy Research Institute and the Laboratoire d'Analyse Régionale et d'Expertise Sociale (IFPRI and LARES 1998) and the data of the survey which was implemented within the Niger basin of Benin in the 2012-2013 agricultural year. Regarding the later survey, three-stage sampling is used. First, communes were randomly chosen within each agro-ecological zone (AEZ), based on their number of agricultural households. Second, 28 villages were randomly selected within selected communes and last, random farm households within selected villages. AEZ V was disregarded, because only one of its communes is located within the Niger basin. The sample size is 545 agricultural households. The questionnaire used is composed of eight sections ranging from demographic information to household assets and basic services.

As for the 1998 small farmer survey, the households were selected using a two-stage stratified random sample procedure based on the 1997 Pre-Census of Agriculture. First, villages were randomly selected in each department, with the number of villages proportional to the volume of agricultural production. Second, in each village, nine households were randomly selected using the list prepared for the Pre-Census. The final sample size was 899 farm households in the country (153 farm households from 14 villages within the Niger basin of Benin). Regarding each data set, aggregation is done at village level using the weights attributed to each farm household. Moreover, additional information on the socioeconomic infrastructures has been collected through an informal discussion with the village chiefs (number of primary, secondary and high schools, number of maternities, communal hospitals, district hospitals, dispensaries, clinics, and drinking water sources). In addition to the primary data, the research benefited socio-economic data from the Institut National de la Statistique et de l'Analyse Economique du Bénin (INSAE) and climatic data from the Agence pour la Sécurité de la Navigation Aérienne en Afrique et à Madagascar (ASECNA). The econometric analysis is on the 14 villages surveyed in 1998 and the 28 of 2012. 


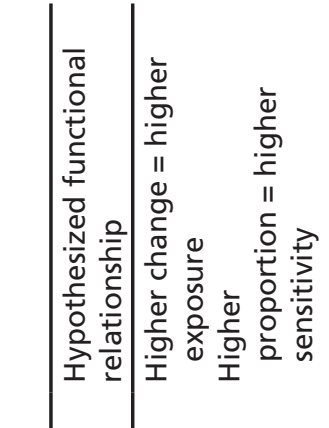

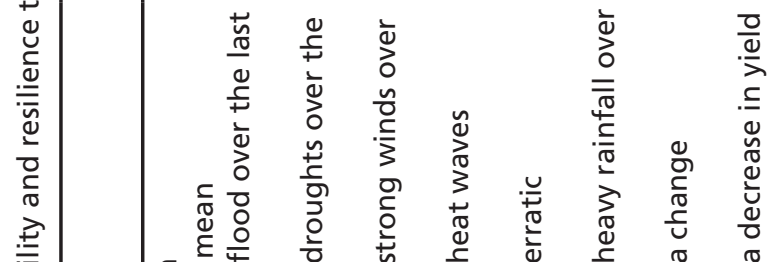

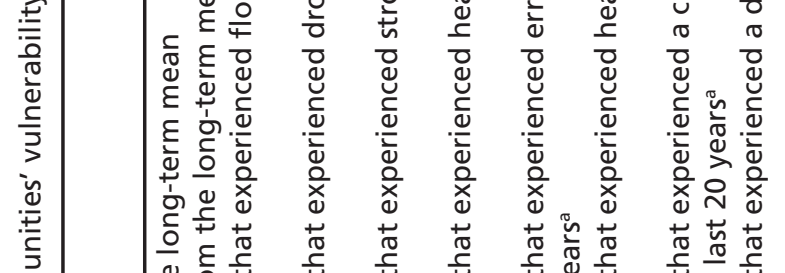




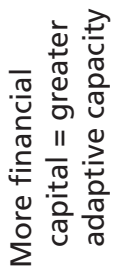

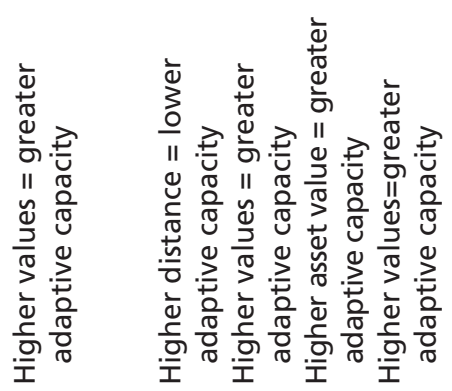

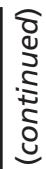
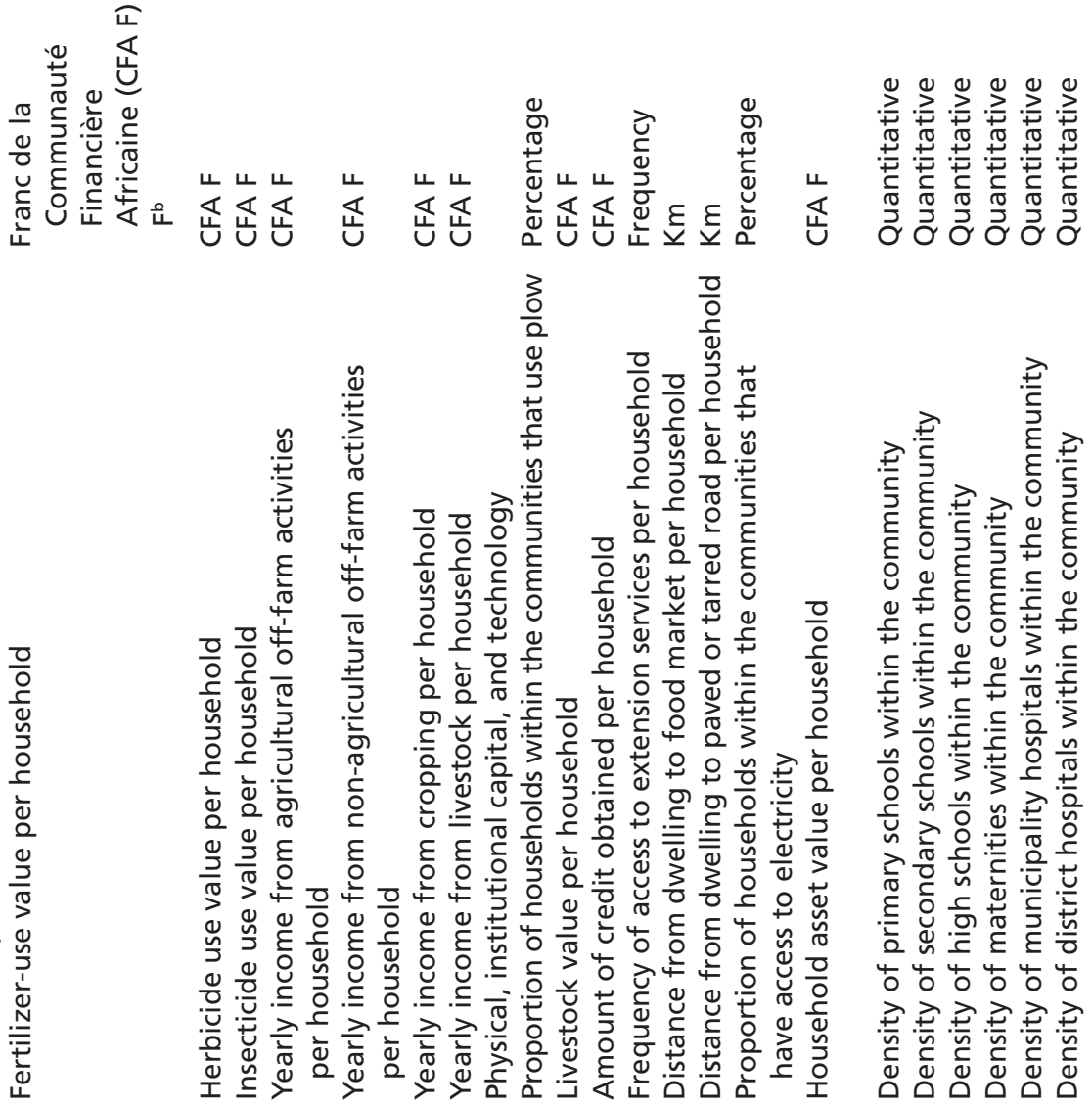

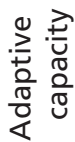




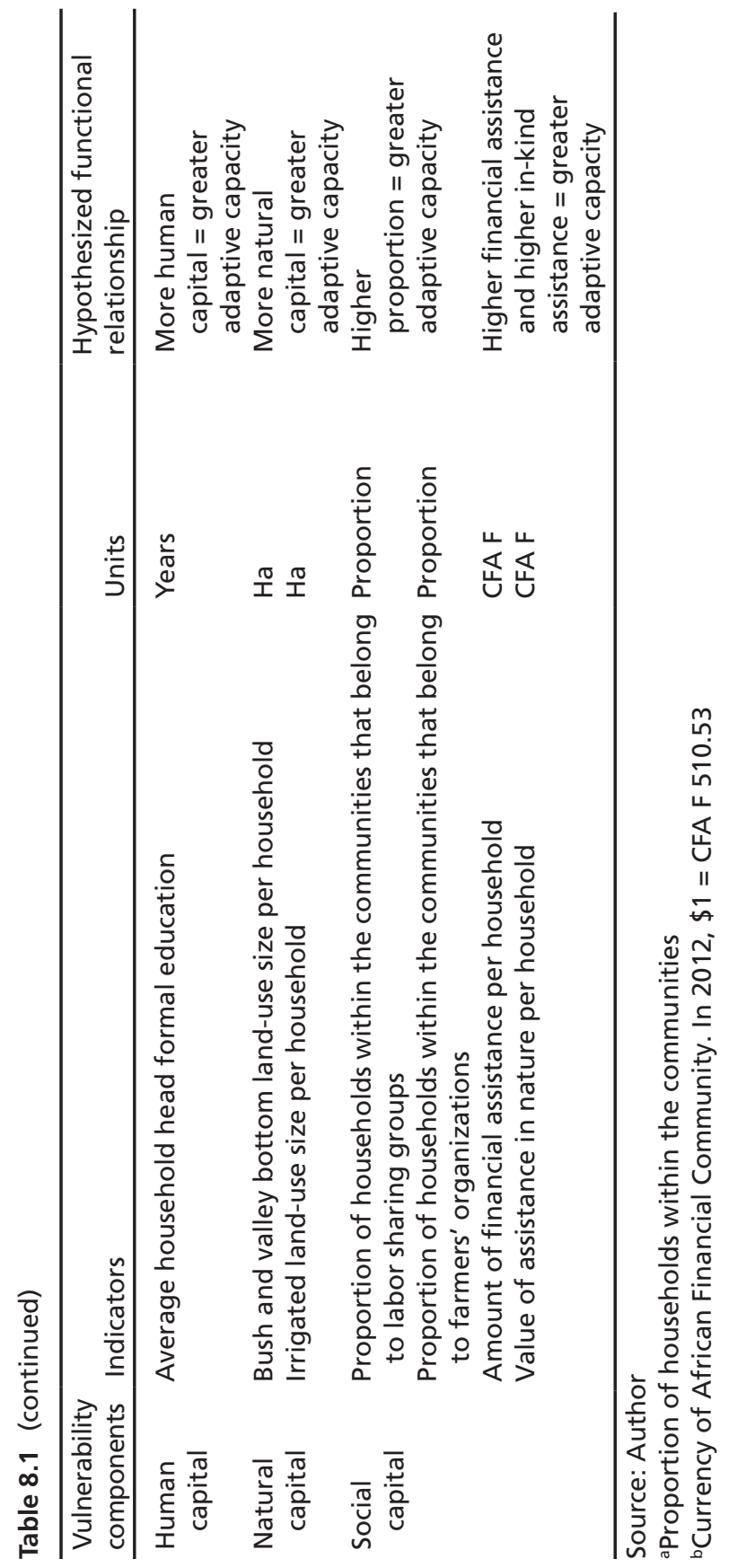


The Niger basin covers $37.74 \%$ of Benin, is located in the extreme north of the country between latitudes $11^{\circ}$ and $12^{\circ} 30^{\prime} \mathrm{N}$ and longitudes $2^{\circ}$ and $3^{\circ} 20^{\prime} 40 \mathrm{E}$, and has an area of $43,313 \mathrm{~km}^{2}$. Five AEZs out of the eight of the country are covered by the basin (wholly and partially). It covers 17 communes, both wholly and partially (12 communes wholly, and 5 partially). These communes belong to 3 departments: Alibori, Atacora, and Borgou. The agricultural sector in Benin employs $70 \%$ of the active population, and contributes $35 \%$ to the GDP, $75 \%$ to export revenue (République du Bénin 2014). The agricultural production is extensive, relies on family labor combined with limited use of improved inputs, production methods, and farm equipment. The country's agricultural trade is characterized by a weak performance, with a persistently negative agricultural trade balance.

\subsection{Results and Discussion}

\subsubsection{Socio-economic Characteristics of the Communities and Environmental Attributes}

The average percentage of farm households that used plows through animal traction within the communities amounted to $61 \%$ and $54 \%$ in 1998 and 2012, respectively. On average, the communities were poor in terms of income and asset ownership. The average yearly income per household within the communities from crop selling was CFA F 636,540.89 in 1998 and 1,423,760.69 in 2012. The value of the assets per household (except land) amounted to an average of CFA F 188,969.93 and 309,607.40 in 1998 and in 2012, respectively. Given that the subsistence and mixed crop-livestock production system was the dominant production system, livestock keeping was common among the surveyed communities. Livestock were used for consumption, traction, and manuring in farming, and as a means for cash income. The majority of cattle owned were for traction purposes. In terms of income from livestock, on average, a household within the communities earned CFA F 248,289.88 and 78,372.93 in 1998 and in 2012, respectively. 
The farm households within the communities actively seemed to participate in off-farm activities to increase their livelihoods. The average yearly income per household from agricultural off-farm activities amounted to CFA F 11,063.49 and 30,596.35 in 1998 and in 2012, respectively. While the average yearly income from non-agricultural off-farm activities amounted to CFA F 96,856.92 and 293,713.73 in 1998 and in 2012, respectively.

Basic services and infrastructure were generally poor in the surveyed villages as is the case with the rest of the country. The communities had generally access to extension services through cotton production. However, in Malanville, a commune located at the vicinity of the Niger River, they had access to extension services through rice production. On average, the farm households had access 0.71 time to extension services in 1998 and 1.18 times in 2012. In fact, cotton production is organized in Benin through the farmers' organizations and $79 \%$ and $36.3 \%$ of the households were members of these organizations in 1998 and 2012, respectively. Access to health care was relatively low (low density of health infrastructures). The average amount of credit received per household within the communities amounted to CFA F 14,952.38 and 19,357.33 in 1998 and in 2012, respectively. Only $10 \%$ of the farm households within the communities had access to electricity in 1998 and 23\% in 2012. Therefore, the percentage of households within the communities that have access to electricity had at least double between 1998 and 2012. However, they were too far away from paved or tarred roads, which meant that they did not have access to adequate roads even though the situation has been improved between the two periods.

Apart from the farmers' organizations, the farm households within the communities worked together through labor-sharing groups. Through labor-sharing groups, they alternated working on the farms of each member of the group. About one-third and a quarter of the farm households (31\% and 24\%) within the communities belonged to at least one laborsharing group in 1998 and in 2012, respectively. The data reveal the existence of social capital in the basin. Indeed, the value of in-kind assistance per household amounted to CFA F 1902.95 in 2012, whereas the financial assistance per household within the communities amounted to 3178.57 and 3364.58 in 1998 and in 2012, respectively. 
As for land ownership, in 1998, two types of tenure were found in the basin: owned land and others (use without paying any fee, and commune property). Land tenure security appeared to be high (at least $50 \%$ of crop land) within the communities except for one village (Donwari) which had $40.75 \%$ of owned land. The situation in 2012 differs relatively from that of 1998. Indeed, in 2012, there were lease and rented land in some communities (e.g., Bodjecali, Garou 1, Tintinmou Peulh, and Perma), although their level is low compared with owned land (at least $75 \%$ of crop land is under tenure security). During the last 20 years, the communities faced many climate shocks. Strong winds were the major climate shock that the communities faced over the last 20 years, followed by erratic rainfall, heavy rainfall, heat waves, floods, and finally droughts. The distribution of the shocks differs across villages.

\subsubsection{Vulnerability and Resilience Levels of the Communities}

Factor scores from the extracted components are employed to construct indices for adaptive capacity (financial capital, physical capital, institutional capital and technology, human capital, natural capital, and social capital), sensitivity, and exposure. The analyses help to understand the situation of 14 villages over time (in 1998 and in 2012) and 28 villages in 2012 (Tables 8.2 and 8.3). Higher values of the vulnerability indices depict less vulnerability, whereas lower values show more vulnerability. It is worth mentioning that on average both 1998 and 2012 were wet years. However, water excess was higher in 1998 than in 2012 (Figs. 8.1 and 8.2). The 1998 survey did not include the sensitivity to climate shocks and therefore, it was not possible to build the sensitivity index for this year. The situation of the villages has been improved except for Kossou, Kpbébéra, Gantiéco, Kota Monongou, and Moupémou.

Sirikou is the less vulnerable community in 2012, whereas the most vulnerable is Kota Monongou. Indeed, Sirikou is in the AEZ II and has a vulnerability index of 3.14. Kota Monongou is in the AEZ IV and has -2.48 as vulnerability index. In 2012 , the range between sensitivity, exposure, and adaptive capacity of the two communities is $1.90,0.59$, and 


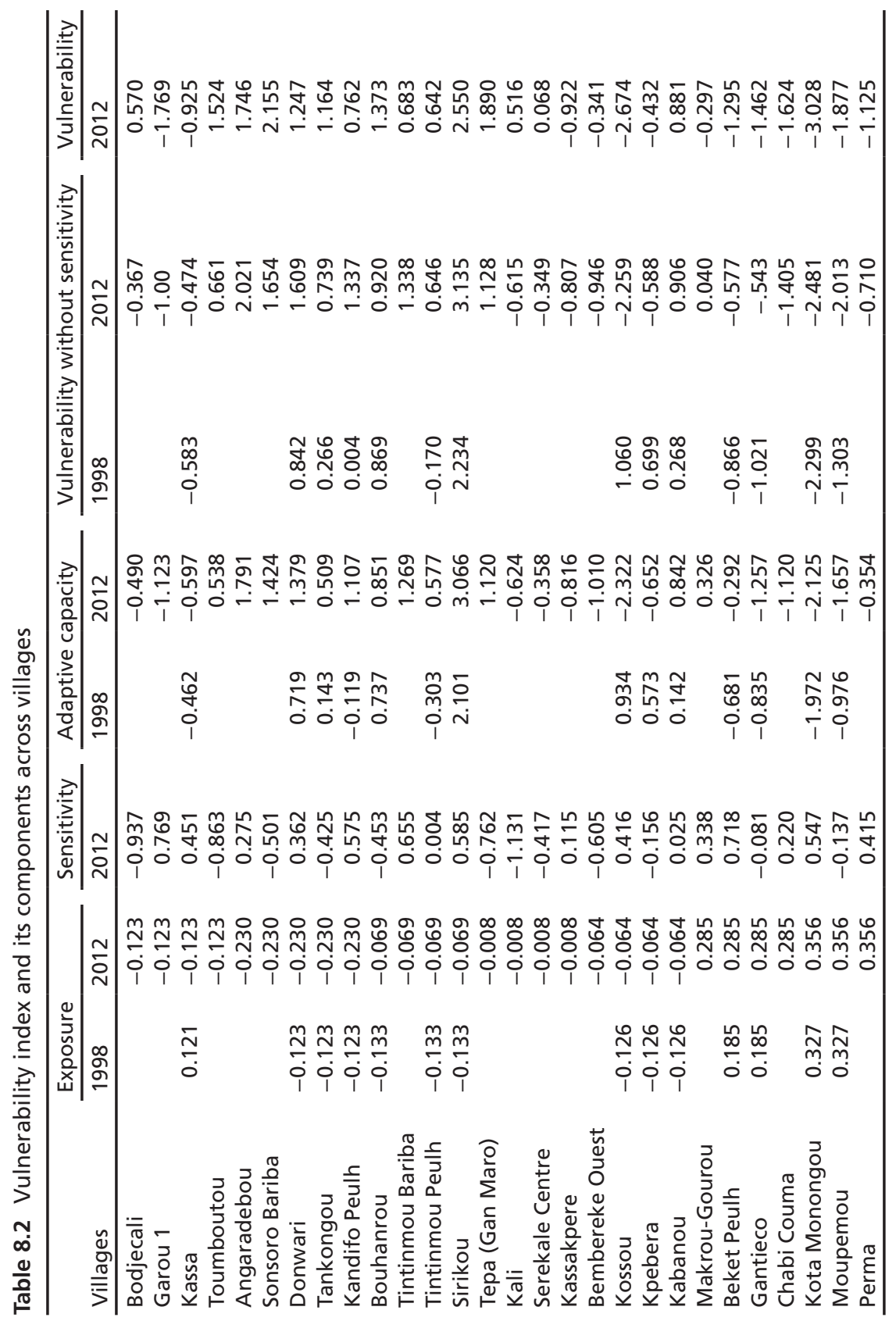




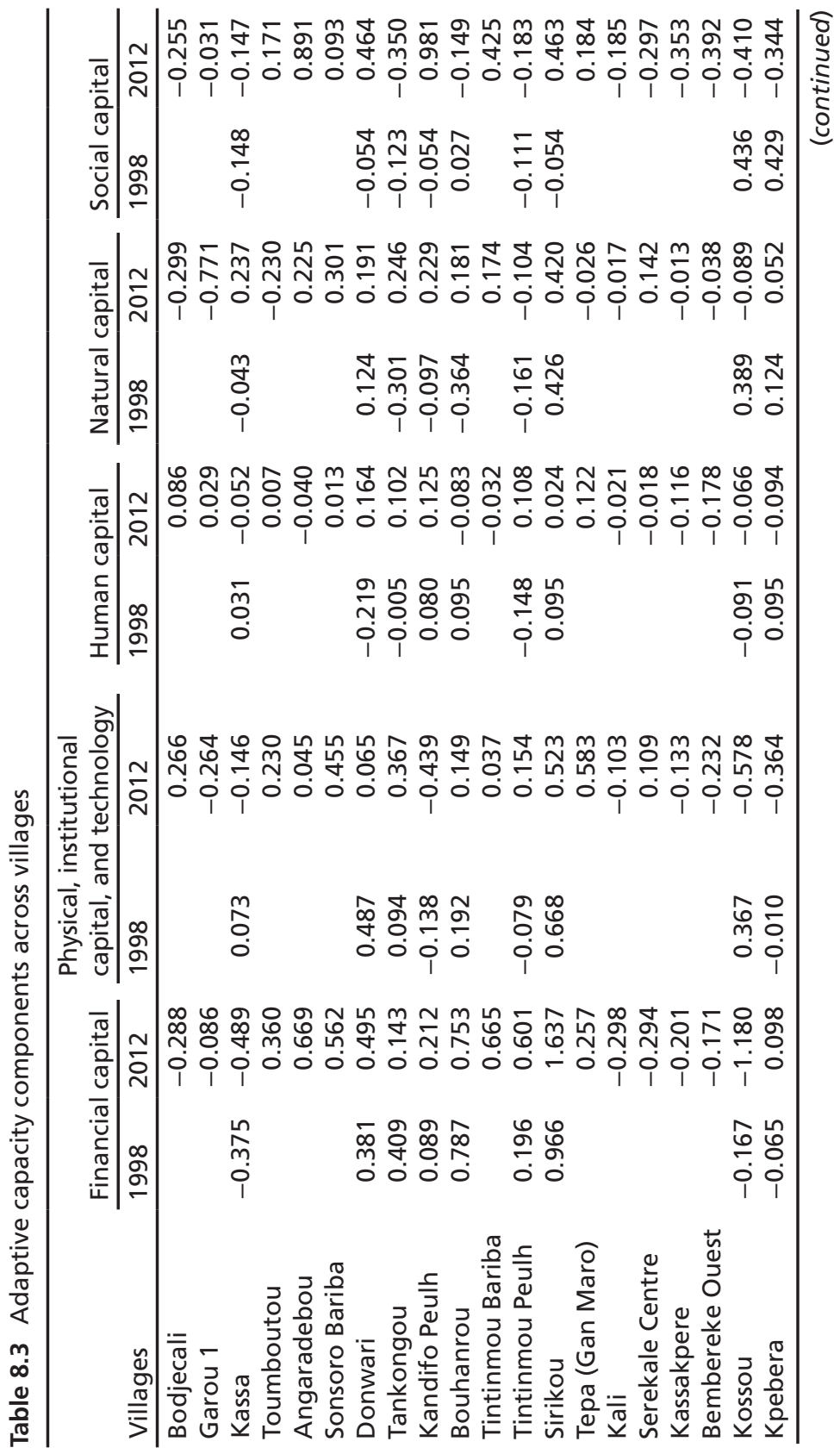




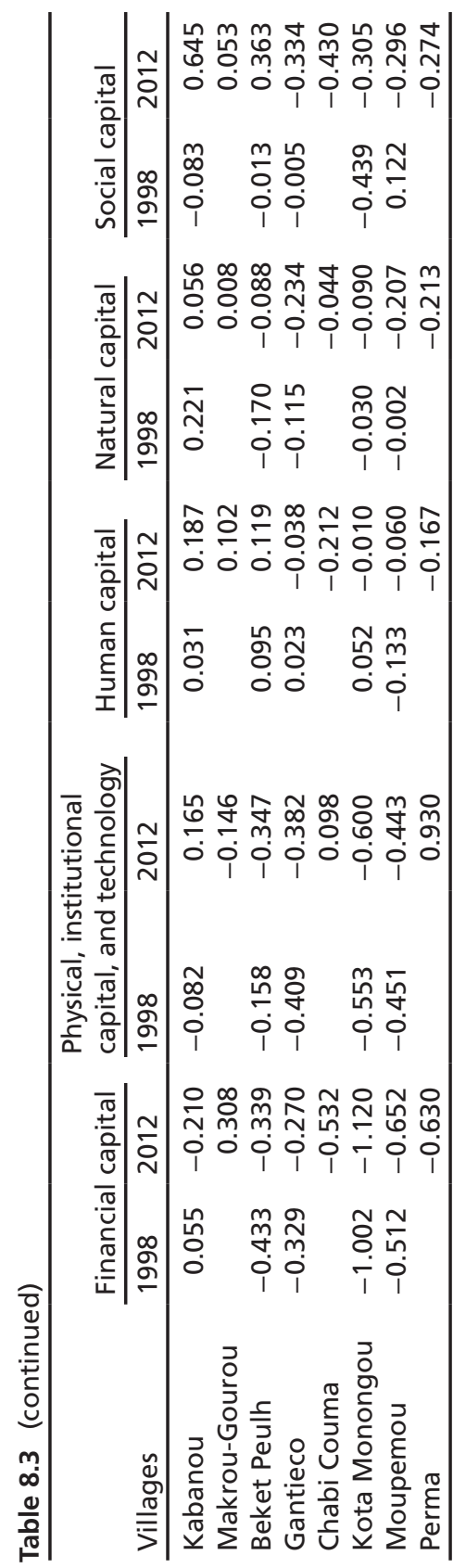




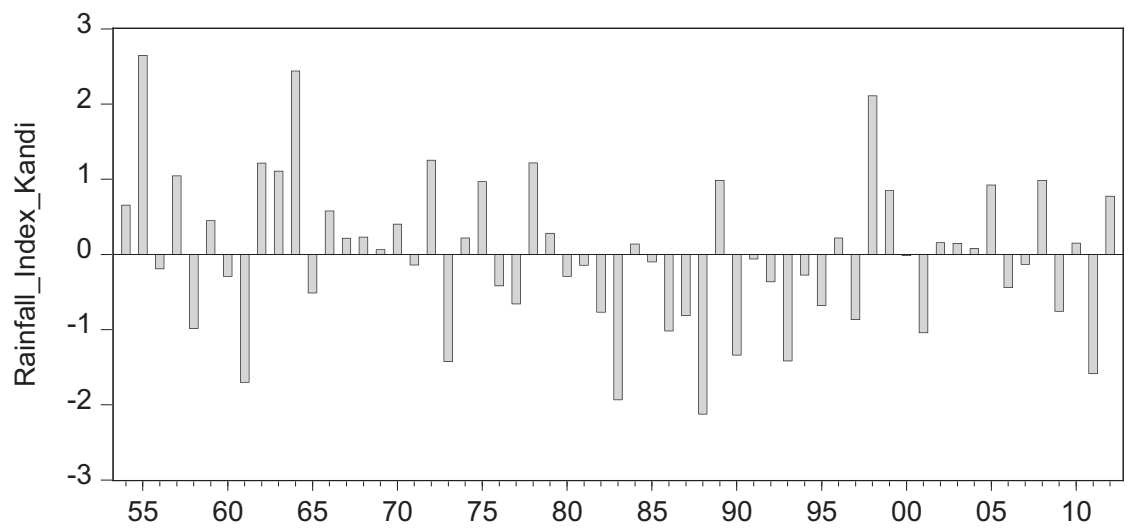

Fig. 8.1 Rainfall index evolution between 1954 and 2012 in Kandi. Note: Rainfall index is calculated using this equation: Rainfall index ${ }_{t}=$ Rainfall $_{t}-$ Mean/Standard deviation

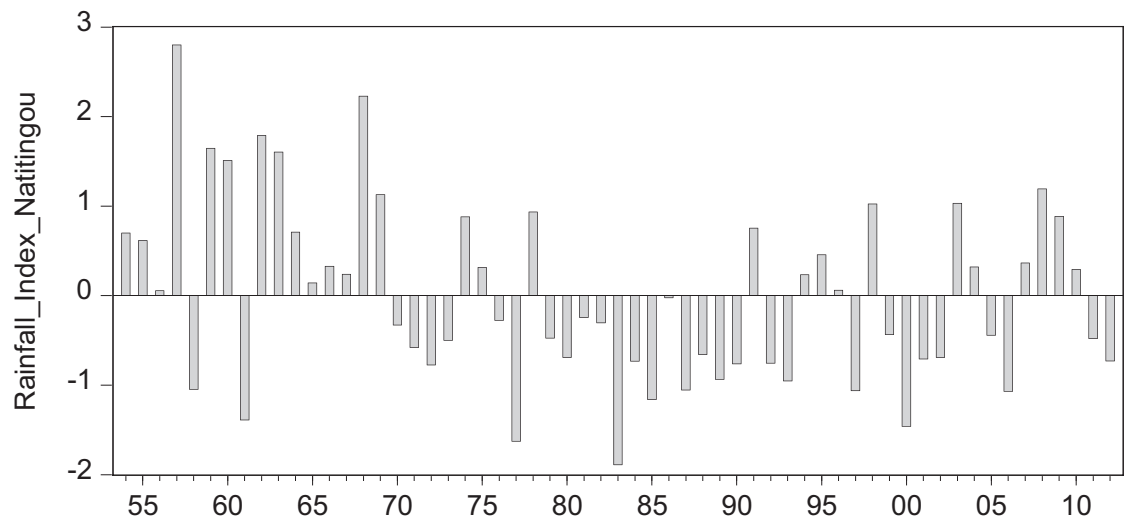

Fig. 8.2 Rainfall index evolution between 1954 and 2012 in Natitingou

5.39, respectively. Even in 1998, Kota Monongou was the most vulnerable and Sirikou the less vulnerable to climate shocks. Indeed, Sirikou has the highest adaptive capacity in 1998 and in 2012. Kota Monongou and Moupémou were the most exposed villages to climate shocks in 1998, while in 2012, the exposure level was similar for all the villages. The villages are classified in terms of vulnerability for the two periods. In 1998, 42.86\% of the communities were vulnerable (without accounting for sensitivity), 
while $53.57 \%$ were vulnerable in 2012 . In terms of overall vulnerability to climate shocks, $46.43 \%$ of the communities were vulnerable in 2012 . Among the communities that were vulnerable in 1998, 83.33\% were still vulnerable in 2012.

As for adaptive capacity, $50 \%$ of the communities lacked it in 1998 and 2012, out of the 14 villages tracked. When considering all the 28 villages in 2012, 53.57\% lacked adaptive capacity. The situation of some villages in terms of adaptive capacity has been improved between 1998 and 2012 (e.g., Kandifo Peulh and Tintinmou Peulh), while some have seen their situation worsened (e.g., Gantieco and Kota Monongou). Therefore, at least half of the communities in the basin appear to be not resilient to climate shocks. The situation differs across the five capitals. Lack in financial capital is relatively common among surveyed communities: $50 \%$ and $53.57 \%$ of the villages lacked financial capital in 1998 and 2012, respectively. Regarding physical, institutional capital, and technology, $57.14 \%$ of the surveyed villages lacked it in 1998, while a decrease in this percentage is noted in 2012 (46.43\%). Therefore, this capital has been improved among the surveyed communities in the basin during the two periods. Although $35.71 \%$ of the communities lacked human capital in 1998, the situation has worsened in 2012; this percentage amounted to $53.57 \%$ in 2012 . On average, the situation in terms of natural capital has been improved among surveyed communities, although it needs improvements. In 1998, 64.29\% lacked natural capital, while in 2012 they were $53.57 \%$ lacking this capital. In 1998, on average, social capital level was quite low, as reflected by the $71.43 \%$ of surveyed villages lacking this capital. Social capital level has been improved in 2012 compared with the situation in 1998, although a large number of communities still lacked this capital (60.71\%). Overall, resilience level is low in the basin.

The degree of vulnerability of the communities across AEZs is also investigated. The communities of AEZ II were the least vulnerable to climate shocks, followed by AEZs I, III, and IV in 2012. Indeed, communities of AEZ IV were the most exposed and the most sensitive to climate shocks, and also had the lowest adaptive capacity. Moreover, communities of AEZ IV had the lowest social capital, whereas communities of AEZ II have the highest. This means that farmers in communities 
of AEZ II helped one another in mitigating the effects of climate shocks, and this leads to their highest resilience level. Even in 1998, communities of AEZ II had the highest adaptive capacity and were the less exposed to climate shocks, whereas communities of AEZ IV had the lowest adaptive capacity and were the most exposed to these shocks. The highest adaptive capacity level of communities of AEZ II was due to their higher financial capital, and physical, institutional capital and technology in 1998. The social capital of communities of AEZ II has been improved over time. The analyses show that, in 1998, communities of AEZ IV lacked all kind of capital; the situation is alarming for financial, physical, and institutional capital, and technology.

\subsubsection{Sensitivity and Uncertainty Analyses}

Vulnerability indices for the two periods were computed 1000 times to map their probability distribution. For each dimension of vulnerability, random values were generated between its minimum and maximum values. The generated vulnerability indices for the two periods follow the normal distribution (Figs. 8.3 and 8.4). Moreover, the reliability of the original calculated vulnerability indices is estimated through determination of the range of the standard deviations around the means, and Student's t-tests revealed that they lie within the respective range $(p<0.05)$. As for sensitivity, the values of some indicators have been changed or some indicators were simply disregarded to explore the influence on vulnerability indices. These analyses showed that the indices are sensitive to these changes.

\subsubsection{Econometric Results}

Panel specification tests have been run through Fisher test and Breusch and Pagan Lagrangian multiplier test. The Fisher test indicates that there are significant individual (village level) effects, implying that pooled ordinary least squared (OLS) would be inappropriate (Prob $>F=0.0 .3$ ). The Breusch and Pagan Lagrangian multiplier test indicates the presence of random effects (Prob $>$ chibar $\left.^{2}=0.06\right)$. Thus, both of these two specification tests 

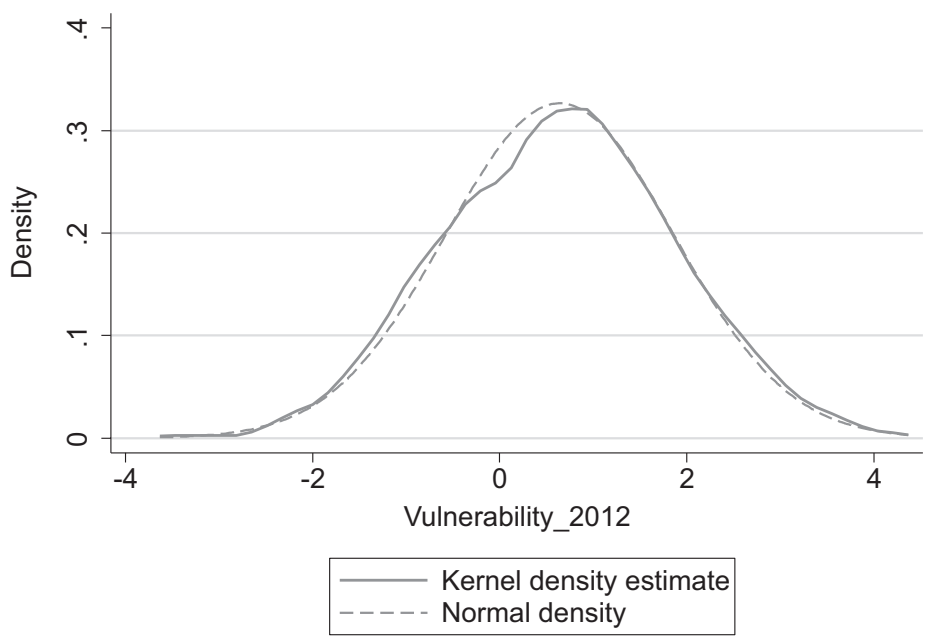

kernel $=$ epanechnikov, bandwidth $=0.2762$

Fig. 8.3 Kernel density of the generated vulnerability index (2012)

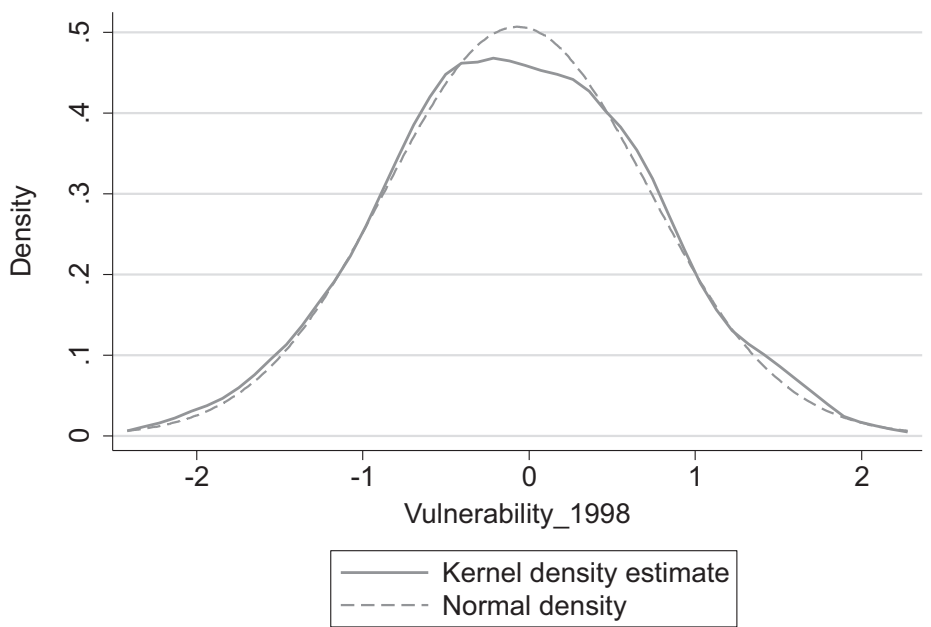

kernel $=$ epanechnikov, bandwidth $=0.1780$

Fig. 8.4 Kernel density of the generated vulnerability index (1998) 
indicate that pooled OLS would be inappropriate (at 5\% and 10\% significance level for the fixed effects and random effects, respectively). The Hausman specification test is used to choose among fixed effects and random effects. Prob $>\mathrm{chi}^{2}=0.11$ leads to the strong non-rejection of the null hypothesis that the difference in coefficients is not systematic. As the time period is short (two periods), random effects seem more appropriate than fixed effects. Consequently, the estimation procedure accounts for the likely endogeneity of land tenure in the random effects model. Table 8.4 presents the results of the estimations.

The impact of the two climate variables is non-linear. A given change in temperature from long-term mean will lessen vulnerability to climate shocks up to 0.35 degree Celsius, and beyond this threshold, the impact will be positive, ceteris paribus. This could be explained by the fact that the crops will gain from carbon fertilization under a change less than 0.35 degree Celsius, ceteris paribus. Regarding precipitations, a given change in rainfall from long-term mean will lessen vulnerability to climate shocks up to $10.79 \%$, and beyond this threshold, the impact will be positive, ceteris paribus. However, the coefficients associated to the change in percentage in rainfall from long-term mean and its square are not significant.

Land tenure security leads to strengthening vulnerability to climate shocks, with the impact being non-significant. This finding suggests that farmers within the communities may not be yet taken advantage of their land tenure status in terms of investments in appropriate technologies relative to farming. This chapter considers also off-farm activities in the analyses of vulnerability, therefore the findings need to be analyzed with respect to that. Lack of tenure security may push farmers within the communities to look for off-farm activities, which are less climate dependent, and therefore, they appear to be less vulnerable through diversifying income sources. However, the result needs to be taken with caution, and needs further investigation in terms of socio-cultural elements that may impede the advantage of having secure tenure.

Membership to farmers' labor-sharing groups and to farmers' organizations appears to be useful for farmers. Indeed, through these organizations, farmers receive relevant information regarding how to deal with farming, such as fertilizer requirements, when to use fertilizers and pesticides, and climatic information. However, the impact of membership to farmers' organizations is higher than the impact of membership to farmers' labor-sharing 
Table 8.4 Regression results of vulnerability

\begin{tabular}{|c|c|c|c|}
\hline \multicolumn{4}{|c|}{ Dependent variable: vulnerability index } \\
\hline Variables & Coefficients & Standard errors & Z-statistics \\
\hline $\begin{array}{l}\text { Change in rainfall from } \\
\text { long-term mean }\end{array}$ & 0.026 & 0.021 & 1.26 \\
\hline $\begin{array}{l}\text { Square of change in rainfall } \\
\text { from long-term mean }\end{array}$ & -0.001 & 0.001 & -1.64 \\
\hline $\begin{array}{l}\text { Change in temperature } \\
\text { from long-term mean }\end{array}$ & $37.605^{* *}$ & 19.118 & 1.97 \\
\hline $\begin{array}{l}\text { Square of change in } \\
\text { temperature from } \\
\text { long-term mean }\end{array}$ & $-54.043^{*}$ & 30.805 & -1.75 \\
\hline $\begin{array}{l}\text { Proportion of households } \\
\text { that belong to farmers' } \\
\text { labor-sharing groups }\end{array}$ & $1.012^{*}$ & 0.562 & 1.80 \\
\hline $\begin{array}{l}\text { Proportion of households } \\
\text { that belong to farmers' } \\
\text { organizations }\end{array}$ & $2.776 * * *$ & 0.745 & 3.73 \\
\hline $\begin{array}{l}\text { Density of primary schools } \\
\text { within the community }\end{array}$ & $96.583 *$ & 55.914 & 1.73 \\
\hline $\begin{array}{l}\text { Percentage of households } \\
\text { that have access to } \\
\text { electricity }\end{array}$ & -0.011 & 0.921 & -0.01 \\
\hline Land tenure security & -0.065 & 0.061 & -1.07 \\
\hline Constant & 2.012 & 4.354 & 0.46 \\
\hline$R$-squared & Overall $=0.522$ & Within $=0.536$ & Between $=0.485$ \\
\hline
\end{tabular}

groups. This could be explained by the fact that farmers had access to extension services mainly through farmers' organizations. These findings confirm the usefulness of social capital in improving welfare as suggested by the literature (Ostrom and Ahn 2007; Ostrom 1994). More primary schools will lessen vulnerability to climate shocks. Indeed, the more the populations are literate, the more they will be able to obtain appropriate information regarding adapting to climate shocks. The impact of the percentage of households that have access to electricity is negative. This finding means that access to electricity is costly to the communities, and it reduces the share of financial means that is invested in adaptation strategies. However, the percentage of households that have access to electricity does not have a significant impact on vulnerability level, ceteris paribus. 


\subsection{Conclusion}

This chapter assesses the vulnerability of communities to climate shocks in the Niger basin of Benin (14 villages tracked between 1998 and 2012, and 14 additional ones in 2012), and analyzes the extent to which land tenure affects vulnerability. First, indices were built for each dimension of vulnerability: adaptive capacity (financial, human, natural, social, physical, and institutional capital, and technology), sensitivity, and exposure. Second, overall vulnerability indices were built. The findings reveal that between 1998 and 2012, the situation of the villages has been improved except for five villages (Kossou, Kpbébéra, Gantiéco, Kota Monongou and Moupémou). Sirikou was the less vulnerable community in 1998 and 2012, whereas the most vulnerable was Kota Monongou. Half of the communities tracked lacked adaptive capacity (through which resilience was analyzed) during the two periods. In 2012, 53.57\% of the 28 communities appeared to have a lack in adaptive capacity. Thus, resilience level is low in the basin. On average, communities of AEZ II were the less vulnerable to climate shocks, followed by AEZs I, III, and IV in 2012. The econometric results suggest that farmers' labor-sharing groups, farmers' organizations, and access to primary education have the potential to lessen vulnerability to climate shocks. Tenure security appears to lead to strengthening non-significantly vulnerability to climate shocks.

The situation of the communities in terms of food and nutrition security will be affected if any action is taken, as the farm households are mainly subsistence farmers. Indeed, this could lead to vulnerability to food insecurity. Therefore, public policies should encourage formal and informal social networks that enable group discussions and better information flows and improve adaptation to climate shocks. They should promote access to primary education and raise the awareness of the farmers within the communities on investment in relevant technology and environmental management practices which have the potential to lessen their vulnerability and strengthen their resilience to climate shocks. Moreover, diversification of income sources off the farm can be promoted. Furthermore, they should think about providing timely climate information to the communities. Results indicating differences among villages and AEZs suggest that adaptation technologies should be targeted to the various villages and AEZs to enhance their specific adaptation potential. 


\section{Appendix}

Table 8.5 Descriptive statistics for indicators used to compute vulnerability in 1998

\begin{tabular}{|c|c|c|c|c|}
\hline Indicators & Minimum & Maximum & Mean & $\begin{array}{l}\text { Standard } \\
\text { deviation }\end{array}$ \\
\hline $\begin{array}{l}\text { Change in percentage in } \\
\text { rainfall from the } \\
\text { long-term mean }\end{array}$ & 0.73 & 38.70 & 31.43 & 11.02 \\
\hline $\begin{array}{l}\text { Change in degree in } \\
\text { temperature from the } \\
\text { long-term mean }\end{array}$ & 0.03 & 0.63 & 0.20 & 0.28 \\
\hline $\begin{array}{l}\text { Fertilizer-use value } \\
\text { per household }\end{array}$ & 1889 & 306,702 & 96,438 & $84,375.77$ \\
\hline $\begin{array}{l}\text { Herbicide-use value } \\
\text { per household }\end{array}$ & 1778 & 238,944 & $63,711.69$ & $69,517.54$ \\
\hline $\begin{array}{l}\text { Yearly income from } \\
\text { agricultural off-farm } \\
\text { activities per household }\end{array}$ & 0 & 86,556 & $11,063.49$ & $22,909.61$ \\
\hline $\begin{array}{l}\text { Yearly income from non- } \\
\text { agricultural off-farm } \\
\text { activities per household }\end{array}$ & 0 & 341,000 & $96,856.92$ & $85,931.84$ \\
\hline $\begin{array}{l}\text { Yearly income from cropping } \\
\text { per household }\end{array}$ & 101,089 & $1,817,489$ & $636,540.89$ & $520,734.99$ \\
\hline $\begin{array}{l}\text { Yearly income from livestock } \\
\text { per household }\end{array}$ & 2633 & $1,116,333$ & $248,289.88$ & $312,268.03$ \\
\hline $\begin{array}{l}\text { Percentage of households } \\
\text { that use plow }\end{array}$ & 0 & 1 & 0.61 & 0.39 \\
\hline Livestock value per household & 24,400 & $2,570,000$ & $1,207,054.11$ & $839,804.36$ \\
\hline $\begin{array}{l}\text { Amount of credit obtained } \\
\text { per household }\end{array}$ & 0 & 65,556 & $14,952.38$ & $18,577.30$ \\
\hline $\begin{array}{l}\text { Number of times of access } \\
\text { to extension services per } \\
\text { household }\end{array}$ & 0 & 2 & 0.71 & 0.80 \\
\hline $\begin{array}{l}\text { Distance from dwelling to } \\
\text { food market per household }\end{array}$ & 0 & 2 & 0.65 & 0.54 \\
\hline
\end{tabular}


Table 8.5 (continued)

\begin{tabular}{|c|c|c|c|c|}
\hline Indicators & Minimum & Maximum & Mean & $\begin{array}{l}\text { Standard } \\
\text { deviation }\end{array}$ \\
\hline $\begin{array}{l}\text { Distance from dwelling to } \\
\text { paved or tarred road } \\
\text { per household }\end{array}$ & 0 & 82 & 28.80 & 27.05 \\
\hline $\begin{array}{l}\text { Proportion of households } \\
\text { within the communities that } \\
\text { have access to electricity }\end{array}$ & 0 & 0 & 0.1 & 0.03 \\
\hline Asset value per household & 46,331 & 386,195 & $188,969.93$ & $96,385.50$ \\
\hline $\begin{array}{l}\text { Density of primary schools } \\
\text { within the community }\end{array}$ & 0 & 0.019 & 0.01 & 0.01 \\
\hline $\begin{array}{l}\text { Density of secondary schools } \\
\text { within the community }\end{array}$ & 0 & 0 & 0 & 0 \\
\hline $\begin{array}{l}\text { Density of high schools } \\
\text { within the community }\end{array}$ & 0 & 0 & 0 & 0 \\
\hline $\begin{array}{l}\text { Density of maternities } \\
\text { within the community }\end{array}$ & 0 & 0.003 & 0.0002 & 0.001 \\
\hline $\begin{array}{l}\text { Density of municipality } \\
\text { hospitals within the } \\
\text { community }\end{array}$ & 0 & 0 & 0 & 0 \\
\hline $\begin{array}{l}\text { Density of district hospitals } \\
\text { within the community }\end{array}$ & 0 & 0.003 & 0.0002 & 0.001 \\
\hline $\begin{array}{l}\text { Average household head } \\
\text { formal education }\end{array}$ & 0 & 2 & 0.74 & 0.82 \\
\hline $\begin{array}{l}\text { Bush and valley bottom } \\
\text { land-use size per household }\end{array}$ & 1 & 10 & 3.88 & 2.97 \\
\hline $\begin{array}{l}\text { Irrigated land-use size per } \\
\text { household }\end{array}$ & 0 & 0 & 0.01 & .02 \\
\hline $\begin{array}{l}\text { Proportion of households within } \\
\text { the communities that belong } \\
\text { to labor-sharing groups }\end{array}$ & 0 & 1 & 0.31 & 0.38 \\
\hline $\begin{array}{l}\text { Proportion of households } \\
\text { within the communities } \\
\text { that belong to farmers' } \\
\text { organizations }\end{array}$ & 0 & 1 & 0.79 & 0.33 \\
\hline $\begin{array}{l}\text { Amount of financial assistance } \\
\text { per household }\end{array}$ & 0 & 20,000 & 3178.57 & 5653.17 \\
\hline
\end{tabular}




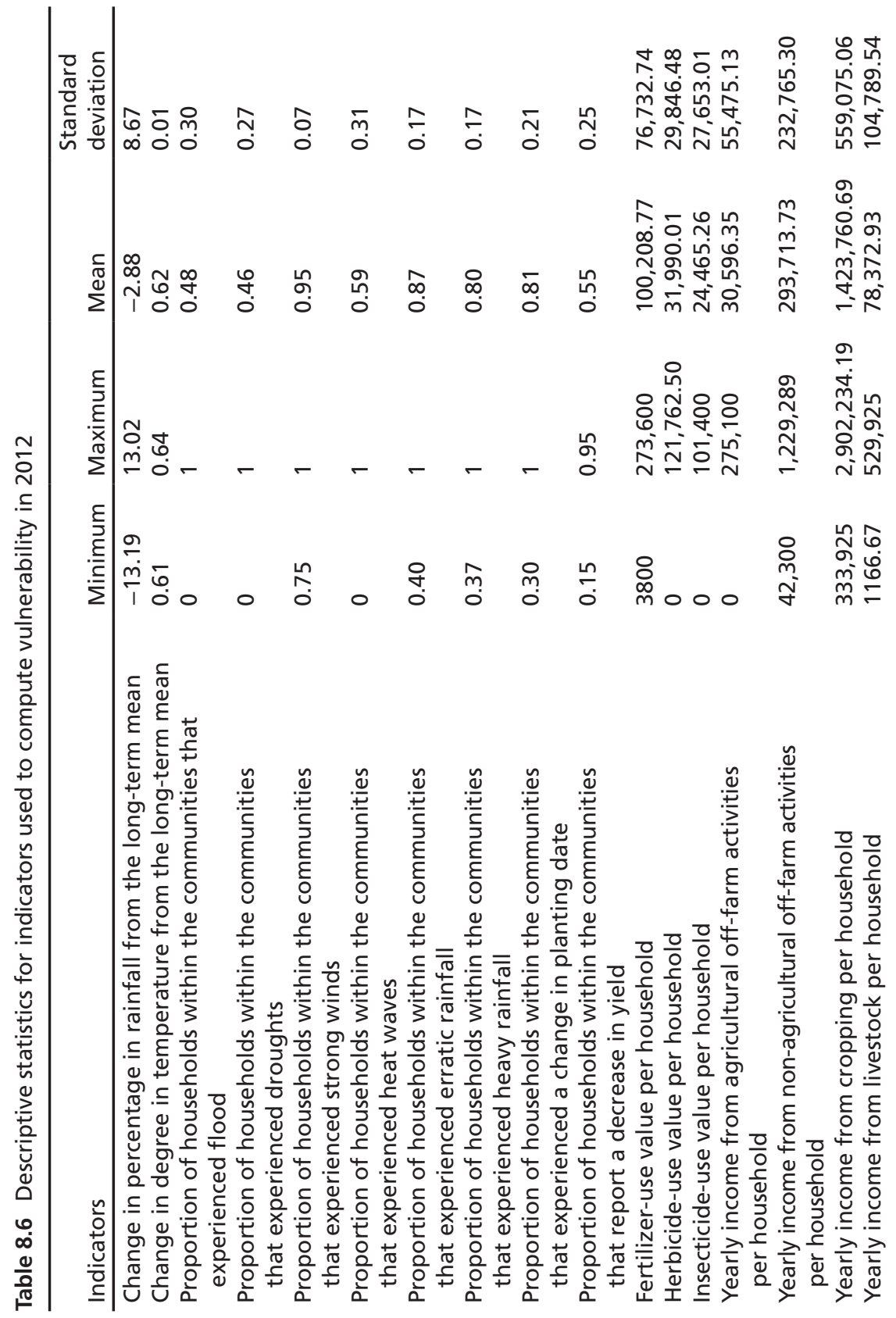




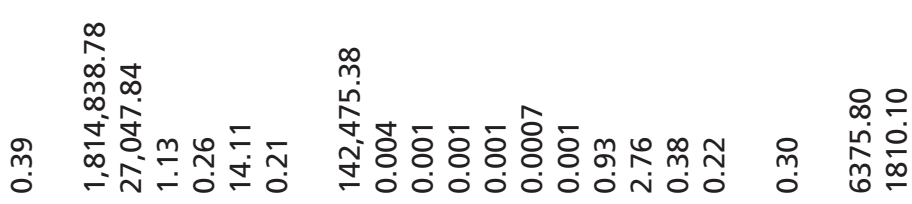

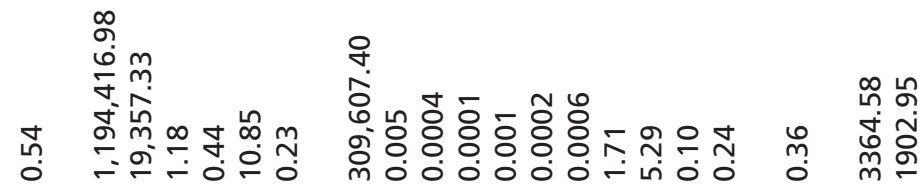
文

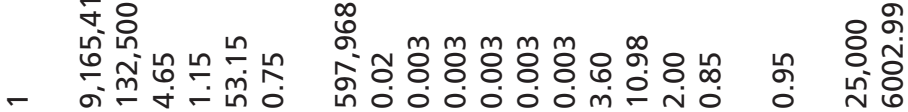

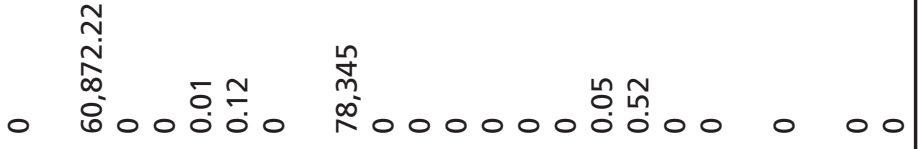

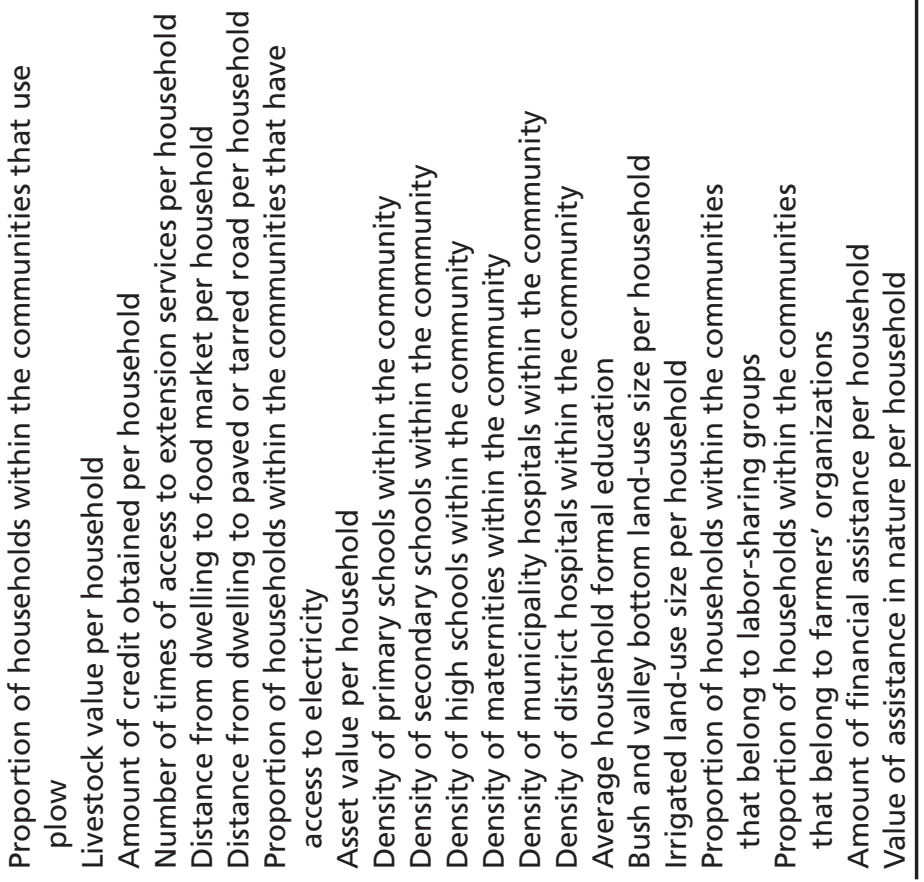


Table 8.7 Factor scores for financial capital

\begin{tabular}{lrrr}
\hline & \multicolumn{3}{c}{ Components } \\
\cline { 2 - 4 } & \multicolumn{1}{c}{ 1 } & \multicolumn{1}{c}{3} \\
\hline Fertilizer-use value per household & 0.37 & 0.01 & -0.04 \\
Herbicide-use value per household & 0.37 & -0.09 & -0.04 \\
Insecticide-use value per household & 0.33 & 0.01 & 0.00 \\
Yearly income from agricultural off-farm & 0.09 & -0.61 & 0.07 \\
$\quad$ activities per household & & & \\
Yearly income from non-agricultural off-farm & -0.07 & 0.21 & -0.65 \\
$\quad$ activities per household & & & \\
Yearly income from cropping per household & 0.03 & 0.53 & -0.01 \\
Yearly income from livestock per household & -0.14 & 0.15 & 0.65 \\
\% of variance & 36.30 & 20.92 & 17.29 \\
\hline
\end{tabular}

Table 8.8 Factor scores for physical and institutional capital, and technology

\begin{tabular}{|c|c|c|c|c|c|}
\hline & \multicolumn{5}{|c|}{ Components } \\
\hline & 1 & 2 & 3 & 4 & 5 \\
\hline $\begin{array}{l}\text { Proportion of households within the } \\
\text { communities that use plow }\end{array}$ & 0.00 & 0.10 & 0.31 & -0.14 & 0.25 \\
\hline Livestock value per household & -0.04 & 0.13 & 0.40 & 0.17 & 0.00 \\
\hline Amount of credit obtained per household & -0.05 & 0.09 & -0.05 & 0.00 & 0.71 \\
\hline $\begin{array}{l}\text { Frequency of access to extension services } \\
\text { per household }\end{array}$ & 0.00 & 0.10 & 0.42 & -0.13 & -0.21 \\
\hline $\begin{array}{l}\text { Distance from dwelling to food market } \\
\text { per household }\end{array}$ & -0.11 & 0.42 & 0.20 & -0.12 & -0.08 \\
\hline $\begin{array}{l}\text { Distance from dwelling to paved or tarred } \\
\text { road per household }\end{array}$ & -0.24 & 0.12 & 0.00 & -0.10 & -0.20 \\
\hline $\begin{array}{l}\text { Proportion of households within the } \\
\text { communities that have access to electricity }\end{array}$ & 0.03 & 0.20 & -0.15 & -0.34 & 0.28 \\
\hline Household asset value per household & 0.26 & -0.22 & 0.14 & 0.10 & 0.12 \\
\hline $\begin{array}{l}\text { Density of primary schools within } \\
\text { the community }\end{array}$ & -0.07 & 0.03 & -0.01 & 0.66 & 0.03 \\
\hline $\begin{array}{l}\text { Density of secondary schools } \\
\text { within the community }\end{array}$ & 0.29 & -0.04 & -0.01 & 0.02 & -0.15 \\
\hline $\begin{array}{l}\text { Density of high schools within } \\
\text { the community }\end{array}$ & -0.09 & 0.38 & 0.07 & 0.19 & 0.09 \\
\hline Density of maternities within the & 0.33 & -0.05 & 0.02 & -0.17 & -0.01 \\
\hline $\begin{array}{l}\text { Density of municipality hospitals } \\
\text { within the community }\end{array}$ & -0.02 & 0.31 & -0.02 & 0.12 & 0.10 \\
\hline $\begin{array}{l}\text { Density of district hospitals within } \\
\text { the community }\end{array}$ & 0.35 & -0.08 & -0.01 & -0.08 & -0.12 \\
\hline$\%$ of variance & 20.74 & 18.46 & 15.82 & 10.16 & 9.46 \\
\hline
\end{tabular}


Table 8.9 Factor scores for human, natural, and social capital

\begin{tabular}{lcrr}
\hline & \multicolumn{3}{c}{ Components } \\
\cline { 2 - 4 } & 1 & 2 & \multicolumn{1}{c}{3} \\
\hline Average household head formal education & -0.123 & -0.295 & 0.168 \\
Bush and valley bottom land-use size per household & -0.01 & 0.263 & 0.483 \\
Irrigated land-use size per household & 0.07 & 0.082 & -0.711 \\
Proportion of households within the communities & 0.413 & -0.196 & 0.034 \\
$\quad$ that belong to labor-sharing groups & & \\
Proportion of households within the communities & 0.344 & -0.057 & 0.118 \\
that belong to farmers' organizations & & & \\
Amount of financial assistance per household & -0.025 & 0.269 & 0.067 \\
Value of assistance in nature per household & -0.257 & 0.72 & -0.041 \\
\% of variance & 29.756 & 19.296 & 15.404 \\
\hline
\end{tabular}

Table 8.10 Factor scores for exposure and sensitivity

\begin{tabular}{|c|c|c|c|}
\hline & \multicolumn{3}{|c|}{ Components } \\
\hline & 1 & 2 & 3 \\
\hline Change in temperature from the long-term mean & -0.124 & 0.486 & 0.063 \\
\hline $\begin{array}{l}\text { Proportion of households that experienced } \\
\text { flood over the last } 20 \text { years }\end{array}$ & 0.265 & -0.189 & -0.227 \\
\hline $\begin{array}{l}\text { Proportion of households that experienced } \\
\text { droughts over the last } 20 \text { years }\end{array}$ & 0.201 & 0.137 & -0.02 \\
\hline $\begin{array}{l}\text { Proportion of households that experienced } \\
\text { strong winds over the last } 20 \text { years }\end{array}$ & 0.218 & 0.051 & 0.037 \\
\hline $\begin{array}{l}\text { Proportion of households that experienced } \\
\text { heat waves over the last } 20 \text { years }\end{array}$ & 0.221 & -0.141 & 0.012 \\
\hline $\begin{array}{l}\text { Proportion of households that experienced } \\
\text { erratic rainfall over the last } 20 \text { years }\end{array}$ & 0.019 & 0.497 & -0.083 \\
\hline $\begin{array}{l}\text { Proportion of households that experienced } \\
\text { heavy rainfall over the last } 20 \text { years }\end{array}$ & 0.238 & -0.105 & 0.174 \\
\hline $\begin{array}{l}\text { Proportion of households that experienced a } \\
\text { change in planting date over the last } 20 \text { years }\end{array}$ & -0.127 & -0.167 & 0.023 \\
\hline $\begin{array}{l}\text { Proportion of households that experienced a } \\
\text { decrease in yield over the last } 20 \text { years }\end{array}$ & 0.039 & 0.11 & -0.54 \\
\hline Change in rainfall from the long-term mean & 0.023 & 0.109 & 0.502 \\
\hline$\%$ of variance & 35.474 & 16.798 & 15.752 \\
\hline
\end{tabular}


Table 8.11 Descriptive statistics of the variables used in the regression

\begin{tabular}{|c|c|c|c|c|}
\hline Variables & Mean & $\begin{array}{l}\text { Standard } \\
\text { deviation }\end{array}$ & Minimum & Maximum \\
\hline Vulnerability & 0.0002 & 1.295 & -2.48 & 3.14 \\
\hline $\begin{array}{l}\text { Change in rainfall from } \\
\text { long-term mean }\end{array}$ & 8.554 & 18.868 & -13.19 & 38.7 \\
\hline $\begin{array}{l}\text { Square of change in rainfall } \\
\text { from long-term mean }\end{array}$ & 420.7 & 560.743 & 0.533 & 1497.69 \\
\hline $\begin{array}{l}\text { Change in temperature } \\
\text { from long-term mean }\end{array}$ & 0.479 & 0.254 & 0.03 & 0.64 \\
\hline $\begin{array}{l}\text { Square of change in } \\
\text { temperature from } \\
\text { long-term mean }\end{array}$ & 0.292 & 0.165 & 0.001 & 0.410 \\
\hline $\begin{array}{l}\text { Proportion of households } \\
\text { that belong to farmers' } \\
\text { labor-sharing groups }\end{array}$ & 0.256 & 0.319 & 0 & 1 \\
\hline $\begin{array}{l}\text { Proportion of households } \\
\text { that belong to farmers' } \\
\text { organizations }\end{array}$ & 0.480 & 0.398 & 0 & 1 \\
\hline $\begin{array}{l}\text { Density of primary schools } \\
\text { within the community }\end{array}$ & 0.006 & 0.005 & 0 & 0.019 \\
\hline $\begin{array}{l}\text { Percentage of households } \\
\text { that have access to } \\
\text { electricity }\end{array}$ & 0.153 & 0.206 & 0 & 0.75 \\
\hline Land tenure security & 92.826 & 12.209 & 40.754 & 100 \\
\hline
\end{tabular}

\section{Notes}

1. The AfDB through its Ten-Year strategy (called the 'High 5s'), is committed to improving food security and rural livelihoods by tackling the most important constraints on agricultural productivity, and to building resilience to climate change (AfDB 2016).

2. Yegbemey et al. (2013) distinguished between inheritance, gifting, renting, and purchasing in Northern Benin.

\section{References}

Adger, N. W. (2006). Vulnerability. Global Environmental Change, 16(3), 268-281.

AfDB. (2016). Annual Development Effectiveness Review 2016: Accelerating the Pace of Change. Abidjan: African Development Bank Group. 
AfDB, OECD, \& UNDP. (2015). African Economic Outlook 2015: Regional Development and Spatial Inclusion. African Development Bank, Organisation for Economic Co-operation and Development, United nations Development. Baltagi, B. H. (2008). Econometric Analysis of Panel Data (4th ed.). West Sussex: John Wiley \& Sons.

Béné, C., Wood, R. G., Newsham, A., \& Davies, M. (2012). Resilience: New Utopia or New Tyranny? Reflection About the Potentials and Limits of the Concept of Resilience in Relation to Vulnerability Reduction Programs. Institute of Development Studies (IDS), Working Paper 2012(405) and Center for Social Protection (CSP), Working Paper 006, Brighton.

Berman, R., Quinn, C., \& Paavola, J. (2012). The Role of Institutions in the Transformation of Coping Capacity to Sustainable Adaptive Capacity. Environmental Development, 2, 86-100.

Brooks, N., Adger, N. W., \& Kelly, M. (2005). The Determinants of Vulnerability and Adaptive Capacity at the National Level and Implications for Adaptation. Global Environmental Change, 15(2), 151-163.

Callo-Concha, D., Gaiser, T., Webber, H., Tischbein, B., Müller, M., \& Ewert, F. (2013). Farming in the West African Sudan Savanna: Insights in the Context of Climate Change. African Journal of Agricultural Research, 8(38), 4693-4705. Chagutah, T. (2013). Land Tenure Insecurity, Vulnerability to Climate-Induced Disaster and Opportunities for Redress in Southern Africa. Jàmbá: Journal of Disaster Risk Studies, 5(2), 1-8.

Cutter, S. L., Barnes, L., Berry, M., Burton, C., Evans, E., Tate, E., \& Jennifer, W. (2008). A Place-Based Model for Understanding Community Resilience to Natural Disasters. Global Environmental Change, 18(4), 598-606. https:// doi.org/10.1016/j.gloenvcha.2008.07.013.

Davies, M., Guenther, B., Leavy, J., Mitchell, T., \& Tanner, T. (2008). 'Adaptive Social Protection': Synergies for Poverty Reduction. IDS Bulletin, 39(4), 105-112.

Davies, M., Oswald, K., \& Mitchell, T. (2009). Climate Change Adaptation, Disaster Risk Reduction and Social Protection. In OECD, Promoting ProPoor Growth: Social Protection (pp. 201-217). Paris: Organisation for Economic Cooperation and Development

Deressa, T. T., Hassan, R. M., \& Ringler, C. (2009). Assessing Household Vulnerability to Climate Change: The Case of Farmers in the Nile Basin of Ethiopia. International Food Policy Research Institute, Discussion Paper 00935, Washington, DC.

Deressa, T. T., Hassan, R. M., \& Ringler, C. (2008). Measuring Ethiopian Farmers' Vulnerability to Climate Change Across Regional States. International Food Policy Research Institute, Discussion Paper 00806, Washington, DC. 
Devereux, S., \& Sabates-Wheeler, R. (2004). Transformative Social Protection. Working Paper 232, Institute of Development Studies, Brighton.

Dixon, R. K., Smith, J., \& Guill, S. (2003). Life on the Edge: Vulnerability and Adaptation of African Ecosystems to Global Climate Change. Mitigation and Adaptation Strategies for Global Change, 8(2), 93-113.

Dunford, R., Harrison, P. A., Jäger, J., Rounsevell, M. D., \& Tinch, R. (2015).

Exploring Climate Change Vulnerability Across Sectors and Scenarios Using Indicators of Impacts and Coping Capacity. Climatic Change, 128(3), 339-354.

Economic Commission for Africa. (2003). Land Tenure Systems and Sustainable Development in Southern Africa. ECA/SA/EGM. Land/2003/2, United Nations Economic Commission for Africa, Southern Africa Office, Lusaka. Etwire, P. M., Al-Hassan, R. M., Kuwornu, J. K., \& Osei-Owusu, Y. (2013). Application of Livelihood Vulnerability Index in Assessing Vulnerability to Climate Change and Variability in Northern Ghana. Journal of Environment and Earth Science, 3(2), 157-170.

Fofana, I. (2011). Simulating the Impact of Climate Change and Adaptation Strategies on Farm Productivity and Income: A Bioeconomic Analysis. Discussion Paper 01095, International Food Policy Research Institute, Washington, DC. Füssel, H.-M. (2007). Vulnerability: A Generally Applicable Conceptual Framework for Climate Change Research. Global Environmental Change, $17(2), 155-167$.

Gavian, S., \& Fafchamps, M. (1996). Land Tenure and Allocative Efficiency in

Niger. American Journal of Agricultural Economics, 78(2), 460-471.

Holling, C. S. (1973). Resilience and Stability of Ecological Systems. Annual Review of Ecology and Systematics, 4(1973), 1-23.

IFPRI, \& LARES. (1998). National Survey of Small Farmers in Benin. International Food Policy Research Institute, and Laboratoire d'Analyse Régionale et d'Expertise Sociale, Washington, DC.

IPCC. (2013). Climate Change 2013: The Physical Science Basis. Working Group I Contribution to the Fifth Assessment Report of the Intergovernmental Panel on Climate Change. Cambridge: Cambridge University Press.

IPCC. (2014). Climate Change 2014: Impacts, Adaptation, and Vulnerability. Part B: Regional Aspects. Contribution of Working Group II to the Fifth Assessment Report of the Intergovernmental Panel on Climate Change (edited by Barros, V. R., Field, C. B., Dokken, D. J., Mastrandrea, M. D., Mach, K. J., Bilir, T. E., Chatterjee, M., et al.). Cambridge: Cambridge University Press. Islam, M. M., Sallu, S., Hubacek, K., \& Paavola, J. (2014). Vulnerability of Fishery-Based Livelihoods to the Impacts of Climate Variability and Change: 
Insights from Coastal Bangladesh. Regional Environmental Change, 14(1), 281-294.

Jayne, T. S., Yamano, T., Weber, T. M., Tschirley, D., Benfica, R., Chapoto, A., \& Zulu, B. (2003). Smallholder Income and Land Distribution in Africa: Implications for Poverty Reduction Strategies. Food Policy, 28, 253-275.

Kelly, M., \& Adger, W. N. (2000). Theory and Practice in Assessing Vulnerability to Climate Change and Facilitating Adaptation. Climatic Change, 47(4), 325-352.

Klein, R. J., Nicholls, R. J., \& Thomalla, F. (2003). Resilience to Natural Hazards: How Useful Is This Concept? Environmental Hazards, 5(1-2), 35-45.

Lokonon, B. O. K. (2017). Farmers' Vulnerability to Climate Shocks: Insights from the Niger Basin of Benin. Working Paper Series No. 248, African Development Bank, Abidjan.

Mahadevia, D. (2011). Tenure Security and Urban Social Protection in India. Research Report 05, Institute of Development Studies, Centre for Social Protection, Sussex.

Malone, E. L. (2009). Vulnerability and Resilience in the Face of Climate Change: Current Research and Needs for Population Information. PNWD-4087, Battelle Memorial Institute, Washington.

Metropolis, N., \& Ulam, S. (1949). The Monte Carlo Method. Journal of the American Statistical Association, 44(247), 335-341.

Ostrom, E. (1994). Constituting Social Capital and Collective Action. Journal of Theoretical Politics, 6(4), 527-562.

Ostrom, E., \& Ahn, T. K. (2007). The Meaning of Social Capital and Its Link to Collective Action. Bloomington: Indiana University, Workshop in Political and Policy Analysis.

Pearson, K. (1901). On Lines and Planes of Closest Fit to Systems of Points in Space. Philosophical Magazine, 2, 559-572.

République du Bénin. (2014). Analyse Globale de la Vulnérabilité et de la Sécurité Alimentaire. Cotonou, Benin: INSAE.

Schickele, R. (1952). Theories Concerning Land Tenure. Journal of Farm Economics, 34(5), 734-744.

Scoones, I. (1998). Sustainable Rural Livelihoods: A Framework for Analysis. Institute of Development Studies, Working Paper 72, Brighton.

Shewmake, S. (2008). Vulnerability and the Impact of Climate Change in South Africa's Limpopo River Basin. International Food Policy Research Institute, Discussion Paper 00804, Washington, DC.

Simane, B., Zaitchik, B. F., \& Foltz, J. D. (2016). Agroecosystem Specific Climate Vulnerability Analysis: Application to the Livelihood Vulnerability 
Index to a Tropical Highland Region. Mitigation and Adaptation Strategies for Global Change, 21(1), 39-65.

Solórzano, A. (2016). Can Social Protection Increase Resilience to Climate Change?: A Case Study of Oportunidades in Rural Yucatan, Mexico. IDS Working Paper 465, Center for Social Protection, Institute of Development Studies, Brighton. Stern, N. (2008). Key Elements of a Global Deal on Climate Change. London: London School of Economics and Political Science.

Tesso, G., Emana, B., \& Ketema, M. (2012). Analysis of Vulnerability and Resilience to Climate Change Induced Shocks in North Shewa, Ethiopia. Agricultural Sciences, 3(6), 871-888.

Turner, B. L. (2010). Vulnerability and Resilience: Coalescing or Paralleling Approaches for Sustainability Science? Global Environmental Change, 20(4), 570-576. https://doi.org/10.1016/j.gloenvcha.2010.07.003.

Vincent, K. (2007). Uncertainty in Adaptive Capacity and the Importance of Scale. Global Environmental Change, 17(1), 12-24.

Vincent, K., \& Cull, T. (2014). Using Indicators to Assess Climate Change Vulnerabilities: Are There Lessons to Learn for Emerging Loss and Damage Debates. Geography Compass, 8(1), 1-12.

Yegbemey, R. N., Yabi, A. J., Tovignan, D. S., Gantoli, G., \& Kokoye, H. S. (2013). Farmers' Decisions to Adapt to Climate Change Under Various Property Rights: A Case Study of Maize Farming in Northern Benin (West Africa). Land Use Policy, 34, 168-175. https://doi.org/10.1016/j.landusepol.2013.03.001.

Open Access This chapter is licensed under the terms of the Creative Commons Attribution 4.0 International License (http://creativecommons.org/licenses/ by/4.0/), which permits use, sharing, adaptation, distribution and reproduction in any medium or format, as long as you give appropriate credit to the original author(s) and the source, provide a link to the Creative Commons license and indicate if changes were made.

The images or other third party material in this chapter are included in the chapter's Creative Commons license, unless indicated otherwise in a credit line to the material. If material is not included in the chapter's Creative Commons license and your intended use is not permitted by statutory regulation or exceeds the permitted use, you will need to obtain permission directly from the copyright holder.

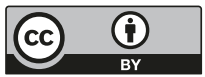

